\title{
Measurement of adenylate cyclase activity in ram spermatozoa
}

\author{
Kristin M. Towns and R. K. J. Luke \\ School of Agriculture, La Trobe University, Bundoora, Victoria 3083, Australia
}

The activity of adenylate cyclase in a preparation is usually determined by measuring the conversion of radioactive ATP to cyclic AMP. Such a procedure has been used to demonstrate the presence of this enzyme in spermatozoa of various species, e.g. monkeys (Casillas \& Hoskins, 1970, 1971) and rams (Tash \& Mann, 1973). Since intact cells are impermeable to ATP (Roll, Weinfeld, Carroll \& Brown, 1956) and since in many tissues adenylate cyclase is associated with the inside of the plasma membrane (Øye \& Sutherland, 1966), tissue homogenates or preparations of cell membrane are normally employed in such assays (Rodbell, 1972). However, during the above-mentioned demonstrations of activity in spermatozoa, the cells were not treated before assay to increase their permeability to ATP. The purpose of the experiments described in this paper was to examine whether higher estimates of adenylate cyclase activity of spermatozoa would be obtained if cells were disrupted before being incubated with ATP.

Semen was collected from 3 rams by electroejaculation and pooled. After collection in calciumfree Krebs-Ringer phosphate, $\mathrm{pH} 7 \cdot 4$ (Krebs, 1933) ejaculates were kept at $30^{\circ} \mathrm{C}$ and washed twice in $30 \mathrm{ml}$ of the same medium. The samples were centrifuged at $800 \mathrm{~g}$ for $20 \mathrm{~min}$ and the spermatozoa re-suspended in the same medium to give a density of $10^{8}$ cells $/ \mathrm{ml}$. Motility of spermatozoa was checked routinely.

The following techniques were used to disrupt spermatozoa before assay for adenylate cyclase activity: (i) freeze-thawing: samples $(2-3 \mathrm{ml})$ of spermatozoa were placed in plastic vials, snapfrozen in liquid nitrogen and thawed at $30^{\circ} \mathrm{C}$; (ii) cold shock: spermatozoa were poured into a test tube which had previously been chilled in ice; (iii) passage through a French pressure cell : a suspension $(5 \mathrm{ml})$ of cells at $4^{\circ} \mathrm{C}$ was passed through an Aminco French pressure cell operated at $60 \mathrm{MPa}$; (iv) homogenization: this was performed by hand at $22^{\circ} \mathrm{C}$ in a ground-glass homogenizer, using 10 passes of the pestle; (v) sonication: 2 bursts, each of $1 \mathrm{~min}$, were given to a 15-ml suspension of spermatozoa at $22^{\circ} \mathrm{C}$ using a $3-\mathrm{mm}$ probe on a Rapidis 600 Ultra-sonic disintegrator, at maximum power.

The procedure followed for measurement of adenylate cyclase and phosphodiesterase activity was that described as Method C (in "Note added in Proof") by Salomon, Londos \& Rodbell (1974). Reactions were terminated and cyclic AMP purified as recommended by these authors. Recovery of cyclic AMP from the Dowex and alumina columns was $57 \%$. In addition to enzyme in KrebsRinger phosphate $(50 \mu \mathrm{l})$, reaction mixtures for adenylate cyclase assay (total volume $0 \cdot 1 \mathrm{ml}$ ) contained $2.5 \mu \mathrm{mol}$ tris- $\mathrm{HCl}\left(\mathrm{pH} \mathrm{7.4)}, 0.15 \mu \mathrm{mol}\right.$ ATP (including $5 \times 10^{5} \mathrm{ct} / \mathrm{min}\left[\alpha_{-}^{32} \mathrm{P}\right] \mathrm{ATP}$ ), 0.5 $\mu \mathrm{mol}$ phosphoenolpyruvate, 2 units pyruvate kinase, $0.1 \mu \mathrm{mol}$ cyclic $\mathrm{AMP}, 0.5 \mu \mathrm{mol} \mathrm{MgCl}_{2}$ and $1 \mu \mathrm{mol} \mathrm{KCl}$. Unless otherwise specified, reaction mixtures were incubated for $20 \mathrm{~min}$ at $37^{\circ} \mathrm{C}$. Production of cyclic AMP as a function of incubation time was linear for more than $20 \mathrm{~min}$.

Phosphodiesterase activity was measured by following the disappearance of $\left[8-{ }^{3} \mathrm{H}\right] c y c l i c$ AMP over $120 \mathrm{~min}$ from a reaction mixture (total volume $0.1 \mathrm{ml}$ ) containing $0.1 \mu \mathrm{mol}$ cyclic AMP (including $30,000 \mathrm{ct} / \mathrm{min}\left[8-{ }^{3} \mathrm{H}\right.$ ]cyclic AMP), $0.5 \mu \mathrm{mol} \mathrm{MgCl}_{2}, 1 \mu \mathrm{mol} \mathrm{KCl}$ and $2.5 \mu \mathrm{mol}$ tris- $\mathrm{HCl}, \mathrm{pH} \mathrm{7.4}$. Microscopic examination was carried out on stained (Giemsa) smears.

Under the conditions used in these experiments it is clear that freeze-thawing results in the greatest increase in adenylate cyclase activity, followed in order by cold-shock, passage through the French press and sonication. Homogenizing had no effect. Similarly, phosphodiesterase activity was highest after freeze-thawing, while cold-shocked cells showed a smaller increase in activity than did untreated cells (Table 1). 
Table 1. Effects of various cell-breaking procedures on adenylate cyclase and phosphodiesterase activities in ram spermatozoa

\begin{tabular}{lcc}
\hline \multicolumn{1}{c}{ Treatment } & $\begin{array}{c}\text { Adenylate cyclase activity } \\
\text { (pmol cyclic AMP } \\
\text { formed/10 }\end{array}$ & $\begin{array}{c}\text { Phosphodiesterase activity } \\
\text { (nmol cyclic AMP }\end{array}$ \\
Untreated & $73 \pm 28(24)$ & $36 \pm 9(4)$ \\
Freeze-thaw & $491 \pm 177^{*}(17)$ & $162 \pm 26^{*}(6)$ \\
Cold-shock & $339 \pm 107^{*}(8)$ & $115 \pm 17^{*}(6)$ \\
French press & $275 \pm 57^{*}(4)$ & \\
Homogenization & $79 \pm 21(6)$ & \\
Sonication & $159 \pm 19^{*}(7)$ & \\
\hline
\end{tabular}

Values are means \pm S.D. with no. of observations in parentheses.

* Significantly different from untreated cells $(P<0.01)$.

Examination of stained spermatozoa revealed various degrees of damage. In most of the untreated cells the acrosomes appeared to be intact, but damage was detected in a small proportion of the cells. This took the form of heads being detached from tails or the acrosome being torn. Cells which had passed through the French press or which had been sonicated showed gross damage. Acrosomes were removed and torn, whilst tails and mid-pieces were fragmented. Homogenized and coldshocked cells did not appear different from untreated cells. Cells which had been freeze-thawed showed some tearing of the acrosome and were irregular in outline. No damage to mid-piece or tail could be seen following freeze-thawing.

The results presented here appear to be in conflict with those of Tash \& Mann (1973), who report that cold-shocked spermatozoa lose their ability to form cyclic AMP. One possible reason for this discrepancy is the long assay times ( $30 \mathrm{~min}$ to $2 \mathrm{hr}$ ) used by Tash \& Mann. When we conducted a similar experiment, cold-shocked and freeze-thawed spermatozoa produced cyclic AMP at a constant rate for $30 \mathrm{~min}$, after which the levels decreased, whereas untreated cells showed a steady accumulation of cyclic AMP for $2 \mathrm{hr}$ (Table 2). When larger numbers of freeze-thawed spermatozoa were used, the peak of cyclic AMP and its subsequent removal occurred earlier. Hence, an early peak of enzymatic activity may be missed by assaying after $30 \mathrm{~min}$, especially when large numbers of cells are used.

Table 2. Production of cyclic AMP by freeze-thawed and cold-shocked ram spermatozoa during a 2 -hr incubation

\begin{tabular}{cccc}
\hline & \multicolumn{3}{c}{$\begin{array}{c}\text { Cyclic AMP formed } \\
\text { (nmol/109 } \text { sperm.) }\end{array}$} \\
\cline { 2 - 4 } Time of assay) & Untreated & Freeze-thawed & Cold-shocked \\
\hline 10 & 0.55 & 6.06 & 2.64 \\
20 & 1.19 & 8.41 & 4.65 \\
30 & 1.27 & 9.91 & 7.02 \\
60 & $2 \cdot 12$ & 5.52 & 6.95 \\
120 & 2.67 & 0.38 & 2.38 \\
\hline
\end{tabular}

The patterns of cyclic AMP production and breakdown are controlled mainly by the activities of adenylate cyclase, phosphodiesterase, and to a lesser extent the ATPase systems. The rate of breakdown of cyclic AMP by phosphodiesterase is almost 500 times greater than the rate of formation of cyclic AMP. However, the presence of $1 \mathrm{~mm}$ unlabelled cyclic AMP in the reaction mixture is sufficient to ensure $95 \%$ recovery of cyclic AMP in assays performed for 20 min with untreated cells. Since recovery of cyclic AMP is lower for freeze-thawed and cold-shocked cells $(90 \%)$, it is possible that values of adenylate cyclase activity for these cells have been slightly underestimated. For freeze-thawed and cold-shocked spermatozoa, the recovery of cyclic AMP fell rapidly from $30 \mathrm{~min}$, until at $120 \mathrm{~min}$ little cyclic AMP remained. 
The presence of $5 \mathrm{~mm}$-phosphoenolpyruvate in the reaction mixture is sufficient to maintain an ATP supply during a $2 \mathrm{hr}$ incubation period since untreated cells continue to produce cyclic AMP for this duration of time. Phosphate release from ATP by untreated and freeze-thawed cells has been shown to occur at rates of 1.3 and $1.0 \mu \mathrm{mol} / 10^{9}$ spermatozoa $/ \mathrm{min}$ respectively, with the freezethawed cells consistently showing slower rates than the untreated cells (K. M. Towns, unpublished data). Thus, incubations containing freeze-thawed cells should also contain sufficient substrate to last for $2 \mathrm{hr}$.

In view of the fact that freeze-thawing and cold-shock produce an increase in permeability of sperm membranes to many substances (Mann \& Lutwak-Mann, 1955), it seems probable that the observed increases in adenylate cyclase and phosphodiesterase activity following cold-shock and freeze-thawing are due to increased permeability of the cells to substrate.

Assay of untreated and freeze-thawed spermatozoa in the presence of $20 \mathrm{mM}-\mathrm{MnCl}_{2}$ showed a greater than 20-fold stimulation of adenylate cyclase activity, but both in the presence and absence of $\mathrm{Mn}^{++}$there was a 5-fold difference between the activities of untreated and freeze-thawed cells. The activities in the presence of the $\mathrm{Mn}^{++}$were 2.0 and $10.5 \mathrm{nmol}$ cyclic AMP $/ 10^{9}$ spermatozoa/min respectively. The maintenance of this 5 -fold difference in activity between freeze-thawed and untreated cells, regardless of the presence of $\mathrm{Mn}^{++}$, indicates that the effect of freeze-thawing is to increase the permeability of cells to ATP, rather than to produce a real increase in the activity of adenylate cyclase. A real increase in enzyme activity should either be additional to the increase produced by $\mathrm{Mn}^{++}$, or should overlap this increase.

It is possible that the production of radioactive cyclic AMP by the untreated sample is due to the presence of a small percentage of damaged cells which are permeable to ATP, and not to production of radioactive cyclic AMP by intact cells.

\section{References}

Casillas, E.R. \& Hoskins, D.D. (1970) Activation of monkey spermatozoal adenyl cyclase by thyroxine and triiodothyronine. Biochem. biophys. Res. Commun. 40, 255-262.

Casillas, E.R. \& Hoskins, D.D. (1971) Adenyl cyclase activity and cyclic $3^{\prime}, 5^{\prime}$-AMP content of ejaculated monkey spermatozoa. Archs Biochem. Biophys. 147, 148-155.

KREBS, H.A. (1933) The metabolism of amino acids in the animal body. $Z$. physiol. Chem. 217, 191227.

ManN, T. \& Lutwak-ManN, C. (1955) Biochemical changes underlying the phenomenon of cold-shock in spermatozoa. Archo Sci. biol. 39, 578-588.

ØYe, I. \& Sutherland, E.W. (1966) The effect of epinephrine and other agents on adenyl cyclase in the cell membrane of avian erythrocytes. Biochim. biophys. Acta 127, 347-354.

Rodbell, M. (1972) Methods for the isolation of rat liver plasma membranes and fat cell "ghosts"; an assay method for adenylate cyclase. In Methods in Cyclic Nucleotide Research, pp. 101-124. Ed. M. Chasin. Marcel Dekker Inc., New York.

Roll, P.M., Weinfeld, H., Carroll, E. \& Brown, G.B. (1956) The utilization of nucleotides by the mammal. J. biol. Chem. 220, 439-454.

Salomon, Y., Londos, C. \& Rodbell, M. (1974) A highly sensitive adenylate cyclase assay. Analyt. Biochem. 58, 541-548.

TASH, J.S. \& MANN, T. (1973) Adenosine 3':5'-cyclic monophosphate in relation to motility and senescence of spermatozoa. Proc. R. Soc. B. 184, 109-114.

Received 17 December 1975 